\title{
Selection of construction machine by considering time-cost trade-off problem
}

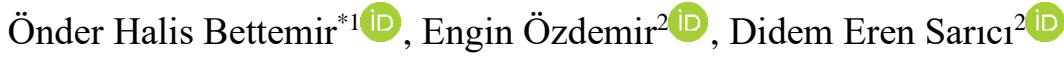 \\ ${ }^{1}$ İnönü University, Department of Civil Engineering, Malatya, Turkey \\ ${ }^{2}$ İnönü University, Department of Mining Engineering, Malatya, Turkey
}

\begin{abstract}
In this study, a decision support system is developed to aid selection of earthwork equipment. Physical and economical attributes of five off the shelf dozers, three excavators, and seven hydraulic hammers are entered to a spreadsheet application. Seven seismic velocity-mechanical property relationships of rock and stiff soil are derived from the literature and defined to the spreadsheet application. Mechanical properties of the soil samples obtained from the construction site are entered to the relevant data cells and seismic velocity to be measured at the field is estimated. Developed system estimates the ripper outputs of the dozers by using ripper production charts, cost and duration of the earthwork task is computed and likelihoods of the feasibility of the construction machines are estimated. Developed system takes the construction duration into account and solves time-cost trade-off problem for the selection of the best construction machine. Developed methodology is implemented on the excavation of the foundations of a mass public housing project with 72 houses. Utilization of ripper production charts without performing seismic velocity tests become possible by the proposed method. Furthermore, time cost trade-off problem is formed and solved without human interruption. The developed decision support system proposes the construction machine with least total direct and indirect costs. Contractors would be able to reduce their construction costs and gain competitive advantage on their rivals, if they implement the proposed system.
\end{abstract}

\section{Keywords}

Time-cost trade-off; Earthwork; Construction planning; Uncertainty

Received: 03 August 2021; Accepted: 24 September 2021

ISSN: 2630-5771 (online) (C) 2021 Golden Light Publishing All rights reserved.

\section{Introduction}

Selection of size and type of construction machine has high effect on the cost and duration of earthwork activities. Therefore, improper selection of a construction machine may have significant adverse effects on the construction projects which have large volumes of earthwork. Inappropriate construction machine may not provide the expected excavation rate and may cause delay in the excavation task which also delays the subsequent activities. Delay of critical activities causes late finish of the construction project and liquidated damages may be charged.

Besides the extension of construction duration, selection of improper construction machine may increase the unit cost of the excavation. Backhoe excavators are not capable of excavating rock and stiff soil types. If the soil is too hard, then the bucket is replaced by hydraulic hammer. Breaking rock or hard soil strata by hydraulic hammer is usually

* Corresponding author

Email: onder.bettemir@inonu.edu.tr 
slower and more expensive than ripping. If volume of the earthwork is large, utilization of hydraulic hammer can be very inefficient in terms of cost and duration.

Dozers can break fissured rocks by ripping with reasonable cost and duration. However, ripping can be implemented if both site conditions and excavation plan is suitable. Irregular, discontinuous, and complicated ripping geometry may reduce the ripping rate and efficiency. If the excavation plan consists of irregular or discontinuous regions, the whole site might have to be ripped which ends up with increased earthwork volume and costs. Solution of this dilemma requires rigorous analysis of excavation costs for both methods. Since the construction is planned under time limitations, only conventional construction methods are analyzed and alternative construction techniques are ignored by the project management team. Therefore, the most suitable construction machine might not be selected.

Earthwork tasks are unique works and therefore, each construction project has to be analyzed in detail to determine the most suitable construction machine. For this reason, superficial and conceptual estimations may lead to inappropriate construction machine selection. However, during bid preparation very few contractors focus on the detailed excavation planning due to tremendous workload on the bid preparation team. Usually direct cost of the construction machine is taken into account and construction duration and its economic effects are usually omitted.

The aforementioned simplifications and assumptions made in order to decrease the bid preparation cost and endeavor may lead to important miscalculations. The state-of-the-art scheduling software does not take the selection of construction equipment into account. The bid is prepared under limited bid preparation budget and time. Therefore, construction schedules are prepared by superficially analyzing the construction machines. This approach may lead to improper selection of construction machine which may lead to low output rates. Changing the construction machine is not applicable during the construction since they are rented long-term. Low output rates are usually compensated by working overtime which increases costs and decreases productivity. This dilemma can be solved by the selection of suitable construction machine before the construction starts. This study aims to provide a solution which can aid the selection of earthwork equipment for the mass housing projects. A decision support system is proposed for the selection of construction machine which takes the cost, duration and volume of the earthwork into account.

\section{Literature review}

Earthwork tasks are complicated and contain uncertainty; therefore, many researchers paid attention on this subject. Kartam and Flood (2000), simulated the earthwork tasks executed by truck and excavator [1]. The construction process is simulated including the hauling of the excavated material without ignoring the variability of the output of the construction machines. Shi and Abourizk (1998) executed the simulation of pipeline construction [2]. Tserng et al. (2000) simulated compaction tasks when more than one compactor is utilized [3]. Paths of trucks and position of compactors are estimated throughout the construction period. Shi et al. (1998) simulated the crane movements for house construction [4]. Saglam and Bettemir (2018) simulated the excavation rate of standard size of backhoe type excavators by Monte Carlo Simulation [5]. The cited studies predict the output of construction machines but ignore the economic effect of the construction duration.

Bettemir (2018) estimated the quantity take-off of excavation by considering the overlaps of the excavation zones [6]. Trivedi and Kumar (2013) developed an Artificial Neural Network system based system for the selection of construction machine. The system provided $7 \%$ decrease in the duration of the construction projects in the average [7]. Munshaw and Trivedi (2016) developed a decision support system for the selection of tower crane type by Artificial Neural Network fed by the tower crane selections of previous constructions 
[8]. Rausch (2010) proposed an integrated system for the estimation of cost and output of construction machines by using the data obtained by Enterprise Resource Planning system [9]. Lim (2018) developed a stochastic system for the selection of excavator by considering the depth of excavation, power of the engine, bucket size, and the site constraints [10]. Karshenas and Farid (1987) and Karshenas (1989) proposed a methodology for the selection of number of dozers and the truck fleet size by considering the cost, capacity and construction duration [11,12]. Chan and Harris (1989) developed a spreadsheet application in which physical and economic attributes of the construction machines are saved by an embedded database. The system provides the best construction machine alternative by considering the user defined criteria [13].

Planning of earthwork activities is complicated because of the selection of suitable construction machine. Contractors aim to allocate a construction machine which provides the least unit cost of earthwork activities. However, this approach minimizes the direct cost and ignores the time related costs which are overhead costs, opportunity costs, and liquidated damages. The purpose of this study is to develop a decision support system which takes both direct and indirect costs of the construction into account and solves the time-cost trade-off problem.

The mentioned studies aim to suggest the optimal construction machine for the user defined construction project. The methods are based on the production charts and curves provided by the manufacturers. The state-of-the art methods both stochastically and deterministically estimate the cost and duration of the construction. On the other hand, the mentioned methods do not take the change in the volume of the earthwork when different construction machine type is selected. The volume of excavation differs when the excavation is executed by a backhoe type excavator or a dozer. A dozer has to excavate the site continuously while an excavator can excavate discrete pits. Therefore the quantity take-off of excavation will depend on the selected construction machine. This study takes the mention attribute into account and the amount of the earthwork is computed according to the selected construction machine. In addition to this, the overhead costs are also considered and the trade-off between the time and the cost is also considered. The proposed model can be beneficial for the contractors since it provides more accurate earthwork volumes and cost estimations than the previous models. A spreadsheet application which computes the duration and cost of the excavation by considering the soil type and bid of quantity of the excavation is developed. Depreciation, spare parts, maintenance and repair, investment, unloading, assembling, fuel, motor oil, and operator costs are computed. In addition to this, excavation rate is computed by considering the soil conditions and the engine power of the construction machine. Furthermore, hauling costs and the required number of trucks are estimated. The contractors can minimize their costs by implementing the suggested approach. The details of the proposed method are given in the Methodology part; implementation of the developed method explains how the cost and duration computations are executed on spreadsheet. Case study is represented in the fourth part, and results are discussed and concluded in the last part.

\section{Methodology}

Ripper rate is estimated by fitting curves to ripper charts. Usage of ripper charts requires seismic velocity measurements. In order to by-pass conducting in-situ seismic velocity measurements, seismic velocity-mechanical property relationships derived from literature survey are used. By entering compressive strength of in-situ material, ripper rate is estimated by the developed model. This approach eliminated the requirement of human intervention and output estimation is made without interruption. Excavation cost and duration is computed by entering the model of construction machine as input parameter. The developed application provides construction cost and duration of the excavation as well as the likelihood of the construction machine being the most suitable one to assist the planning department by reducing their workloads. 
Estimation of cost and duration of earthwork requires the hourly outputs and hourly costs of construction machines. Hourly output depends on the soil conditions and specifications of the construction machine. Soil conditions are determined by site investigations, while specifications of the construction machine are obtained by the tables and charts provided by manufacturers.

In this study, unit price approach of Ministry of Environment and Urbanization of Turkish Republic is implemented [14]. Hourly unit cost of the construction machine is computed by considering the price, engine power, useful life, and yearly work hour of the construction machine. The computation of hourly unit cost is represented in Eqs. 1 to 6 [14].

$$
D C=\frac{A}{N n}
$$

where, $D C$ is hourly depreciation cost, $A$ is the initial purchase price of the equipment, $N$ is the depreciation life of the equipment, and $n$ is the working hours per year. In equation 1, straight line depreciation approach is utilized. Hourly spare parts cost is computed in Eq. 2.

$S P C=0.53 D C$

where, SPC represents hourly cost of spare parts. Hourly cost of maintenance and repair (MRC) is computed as given in Eq. 3 .

$M R C=0.13 D C$

Hourly investment cost of the construction machine is computed by Eq. 4 .

$I C=\frac{i A(N+1)}{2 N n}$

where $\mathrm{i}$ is the capital cost. Hourly unloading and assemble (UC) cost of the construction machine is computed as given in Eq. 5 .

$$
U C=\frac{A}{2 n}
$$

Construction machines are usually powered by diesel engines. The hourly fuel consumption (con) of a diesel engine is estimated by Eq. 6 .

$$
\text { con }=0.0855 \mathrm{~kg} / \mathrm{HP} / \mathrm{hour}
$$

In Eq. 6, HP is the power of the diesel engine in horsepower. The consumed fuel is multiplied by unit price of the fuel and hourly fuel cost (FC) is computed. The lubricating oil cost is assumed to be $20 \%$ of the FC. Hourly workmanship cost (WC) contains the hourly operator cost and foreman. The hourly unit cost of the construction machine (HC) is computed by Eq. 7 .

$H C=D C+S P C+M R C+I C+U C+1.2 * F C+W C$

Hourly excavation rate of the construction machine is estimated by using seismic velocity charts. Excavation rate of the hydraulic hammer is estimated by manuals of the manufacturer [15]. Cost of breaking the rock is obtained by separately considering the costs of hydraulic hammer and the excavator it is attached. Market prices of hydraulic hammer and suitable excavator are obtained and hourly unit costs of the machines are computed by implementing Eq. 1 to 7. However, fuel consumption of the excavator is taken as half of Eq. 6 since the excavator would consume less than average consumption while breaking the rock with hydraulic hammer. Approximate equations for the output and cost estimation for excavators and dozers can be obtained from textbooks [16-17].

Hourly output of dozers is obtained by seismic velocity versus ripper output charts for the corresponding dozer. Seismic velocity measurements are conducted by geophones. Small and medium sized contractors usually do not have geophones in their assets. Moreover, interpretation of seismic data obtained by geophones is difficult and many small and medium sized contractors prefer conducting site investigation based on mechanical properties of the soil.

Mathematical equations between the mechanical properties of soil and seismic velocity are derived in the literature. Seven equations are obtained in order to predict the seismic velocity from unconfined compression strength and Schmidt Hammer readings. The equations are derived to estimate the compressive strength of the rock but in this study the equations are used to estimate the ultrasonic wave velocity by compressive strength. Derived equations are given in Table 1. 
Table 1. Seismic velocity versus compressive strength relationships

\begin{tabular}{lll}
\hline Research No & Research & Compressive Strength Formula \\
\hline 1 & Sharma et al. (2008) [18] & $\mathrm{C}=0.0642 \mathrm{~V}_{\mathrm{p}}-117.99$ \\
2 & Zukui et al. (2001) [19] & $\mathrm{C}=0.0188 \mathrm{~V}_{\mathrm{p}}+0.0648$ \\
3 & Babacan et al. (2012) [20] & $\mathrm{C}=0.012 \mathrm{~V}_{\mathrm{p}}-5.955$ \\
4 & Goktan (1988) [21] & $\mathrm{C}=0.036 \mathrm{~V}_{\mathrm{p}}-31.18$ \\
5 & Christaras et al. (1997) [22] & $\mathrm{C}=9.95 \mathrm{~V}_{\mathrm{p}}^{1.21}$ \\
6 & Altındağ (2012) [23] & $\mathrm{C}=12.746 \mathrm{~V}_{\mathrm{p}}{ }^{1.194}$ \\
7 & Yağız (2011) [24] & $\mathrm{C}=2.304 \mathrm{~V}_{\mathrm{p}}^{3.543}$ \\
\hline
\end{tabular}

In Table 1, $\mathrm{C}$ represents the uniaxial compressive strength of rock and $\mathrm{V}_{\mathrm{p}}$ represents ultrasonic wave velocity. Seismic velocity is used to predict ripper production. This procedure eliminates the requirement of conducting in situ seismic velocity tests.

Ripper charts are analogue data and they cannot be used for automated computations. Typical ripper chart consists of two curves which represent ideal and adverse site conditions respectively. Two parameter exponential curve represented in Eq. 8 is used to estimate ripper production rate.

$$
R=a+\frac{b}{V_{P}^{0,01}}
$$

In Eq. 8, a and $\mathrm{b}$ are polynomial constants which are determined by the boundary conditions of the curve. $V_{P}$ is the seismic velocity represented in 1000 feet per second. Computed coefficients $a$, and $b$ by the ripper charts of Caterpillar dozers are given in Table 2.

Seismic velocity-mechanical property equations give different seismic velocity for the same compressive strength. Ripper rate computations are executed for each seismic velocity. Construction cost and duration are computed for each ripper rate and finally average of the construction cost and duration is reported.

Rock excavation by ripper requires hauling the ripped rocks outside the ripped strip by the dozer. A loader loads the excavated material to trucks. Hauling the ripped material by the dozer blade reduces the ripper output. Haul time of excavated material is computed by the haul distance and
Table 2. Polynomial constants for ripper rate computation

\begin{tabular}{lcccc}
\hline & \multicolumn{2}{c}{ IDEAL } & \multicolumn{2}{c}{ ADVERSE } \\
\cline { 2 - 5 } DOZER & $\mathrm{a}$ & $\mathrm{b}$ & $\mathrm{a}$ & $\mathrm{B}$ \\
\hline D7 & -141937.5 & 145022.0 & -76091.5 & 77690.4 \\
D8 & -162128.6 & 165739.4 & -91309.8 & 93228.4 \\
D9R & -170225.0 & 174026.4 & -101455.4 & 103587.2 \\
D10R & -192365.2 & 196815.6 & -126819.2 & 129483.9 \\
D11R & -232847.3 & 238250.5 & -131692.0 & 134663.3 \\
\hline
\end{tabular}

loaded velocity of the dozer. Empty return time of the dozer is estimated by the empty velocity of the dozer. The aforementioned velocities do not depend on the dozer and nearly the same for each dozer. Maneuver time is given by the user which is determined according to site conditions. Each tour the dozer hauls the rock amount which it can carry. The ripper time required to excavate the carried amount is computed and the total tour time is computed by Eq. 9 .

tourtime $=\frac{V_{\text {Blade }}}{\text { RipperRate }}+t_{\text {Haul }}+t_{\text {Return }}+t_{\text {Spot }}$

Tour time is used to determine the hourly tour number. Hourly output is obtained by multiplying the tour number with blade capacity which is the amount of excavated rock at each tour. Output of a dozer is obtained by Eq. 10 .

output $=\frac{60}{\text { tourtime }} *$ bladecapacity

Duration of the earthwork is predicted by Eq. 11. 
Duration $=\frac{\text { volume of earthwork }}{\text { hourly output of the construction machine }}$

where, Duration is the duration of the excavation in terms of machine-hours. Direct cost of the excavation is computed by multiplying the duration with hourly unit cost of the construction machine. Explained procedure provides the direct construction cost, however total cost of construction is also affected by overhead costs. Total cost of the earthwork is affected by the direct costs of excavation and hauling as well as overhead costs. Crashing the duration of earthwork decreases the indirect costs. Daily cost of construction and possible reward in case the construction is finished earlier are time related costs. Total cost of construction is formed by the summation of direct and indirect costs. Optimum construction duration which provides the minimum total cost is searched. Therefore, the selection of construction machine is a time-cost trade-off problem.

Construction of foundations does not have to wait until the excavation of whole site. Therefore, it is assumed that total construction duration is effected by half of the duration of excavation. Similarly, early finish reward is related with the rent prices. In this case, daily reward is taken as one third of total rent price of the houses. Finally total cost is computed by adding the direct and indirect costs as given in Eq. 12. After the computation of the whole cost items total cost of the earthwork is obtained by Eq. 12 .

Table 3. Specifications of the hydraulic hammers

\begin{tabular}{lccccc}
\hline Dozer Type & Price & $\begin{array}{c}\text { Non-Reinforced } \\
\text { Concrete Output } \\
\left(\mathrm{m}^{3} / \text { day }\right)\end{array}$ & $\begin{array}{c}\text { Reinforced } \\
\text { Concrete Output } \\
\left(\mathrm{m}^{3} / \text { day }\right)\end{array}$ & $\begin{array}{c}\text { Sedimentary } \\
\text { Rock Output } \\
\left(\mathrm{m}^{3} / \text { day }\right)\end{array}$ & $\begin{array}{c}\text { Volcanic Rock } \\
\text { Output }\left(\mathrm{m}^{3} / \text { day }\right)\end{array}$ \\
\hline H110 Es & $€ 24,000$ & $99-214$ & $96-134$ & $84-191$ & $42-99$ \\
H115 Es & $€ 31,000$ & $115-287$ & $107-184$ & $126-229$ & $57-115$ \\
H120 Es & $€ 40,000$ & $153-344$ & $122-229$ & $153-260$ & $84-153$ \\
H130 Es & $€ 51,000$ & $210-375$ & $153-268$ & $191-306$ & $103-210$ \\
H140 Es & $€ 65,000$ & n.a. & $191-497$ & $229-535$ & $115-268$ \\
H160 Es & $€ 78,000$ & n.a. & $229-650$ & $268-688$ & $153-459$ \\
H180 Es & $€ 130,000$ & n.a. & $295-1301$ & $337-1345$ & $210-757$ \\
\hline
\end{tabular}

TotalCost $=$ DirectCost +

(DailyOverheadCost +

DailyOpportunityCost) $*$ duration

Seven different seismic velocities provide different excavation cost and duration. Standard deviation of the cost values are computed by the standard deviation formula according to normal distribution [25]. Standard deviation of the mean cost is used for probability computations.

\section{Implementation of the developed model}

Developed model compares the cost and duration of rock excavation by hydraulic hammer and rock ripping by dozers. Necessary computations are systematically formulated on a spreadsheet and in this part the formulation is explained.

Output of hydraulic hammer is estimated by the charts provided by the manufacturers. Derived data is given in Table 3. Aforementioned data are entered into spreadsheet application. In addition to this, suitable excavator which fits to the examined hydraulic hammer is assigned by the developed application. Hourly output is computed according to the selected hydraulic hammer. Fixed and operating costs of both the hydraulic hammer and the excavator are computed. Total cost of the excavation by hydraulic hammer is computed by taking the direct and indirect costs into account.

Implementation of cost computation for hydraulic hammer is shown in Fig. 1. User can select the hydraulic hammer as drop down list and the data of the cells are updated according to the selected hammer. 


\begin{tabular}{|c|c|c|c|c|c|c|c|}
\hline Hydraulic Hammer (HH) & & & H110Es & 30,24 & 191 & 137,5 & 84 \\
\hline Hammer Type & H130Es & - & H115Es & 39,06 & 229 & 177,5 & 126 \\
\hline Excavator & C 320 & & $\mathrm{H} 120 \mathrm{Es}_{\mathrm{s}}$ & 50,4 & 260 & 206,5 & 153 \\
\hline Fixed Cost of $\mathrm{HH}$ & 0,0002 & & H130Es & 64,26 & 306 & 248,5 & 191 \\
\hline Fixed Cost of Ex & 0,000171 & & H140Es & 81,9 & 535 & 382 & 229 \\
\hline Hydraulic Hammer Cost & 578,34 & TL/day & H160Es & 98,28 & 688 & 478 & 268 \\
\hline Excavator Cost & 3660,12 & $\mathrm{TL} /$ day & H180Es & 163,8 & 1345 & 841 & 337 \\
\hline Total Unit Cost & 4238,46 & $\mathrm{TL} /$ day & & Fixed Cost TL/h & $\mathrm{FC}$ & $\mathrm{OC}$ & TC \\
\hline \multirow[t]{2}{*}{ Output } & 248,5 & $\mathrm{~m}^{3} /$ day & C 315 & 229,824 & 66 & 33,6 & 329,424 \\
\hline & & & C 320 & 287,28 & 85,8 & 33,6 & 406,68 \\
\hline \multirow[t]{2}{*}{ Duration } & 70 & days & C 329 & 363,888 & 105,6 & 33,6 & 503,088 \\
\hline & & & C 349 & 526,68 & 132 & 33,6 & 692,28 \\
\hline Breaking Cost & 296692,2 & $\mathrm{TL}$ & & & & & \\
\hline Hauling Cost & 88550,4 & $\mathrm{TL}$ & & & & & \\
\hline Opportunity Cost & 38500 & $\mathrm{TL}$ & & & & & \\
\hline COST of Excavation with $\mathrm{HH}$ & 423743 & $\mathrm{TL}$ & & & & & \\
\hline & & & & & & & \\
\hline
\end{tabular}

Fig. 1. Spreadsheet application to compute hourly cost and output of hydraulic hammer

Hydraulic hammers can be attached to particular excavator. Therefore suitable excavator is defined for each hydraulic hammer and cost information for the excavator is also defined to the spreadsheet. Selection of appropriate excavator is ensured by the following formula.

AsgnEx $=$ $\mathrm{IF}(\mathrm{OR}(\mathrm{C} 3=\mathrm{F} 2 ; \mathrm{C} 3=\mathrm{F} 3) ; \mathrm{F} 10 ; \mathrm{IF}(\mathrm{OR}(\mathrm{C} 3=\mathrm{F} 4 ; \mathrm{C} 3=\mathrm{F} 5)$ ;F11;IF(C3=F6;F12;IF(OR(C3=F7;C3=F8);F13;0 )$))$

In Eq. 13 AsgnEx, means the assigned excavator. The equation assigns an excavator according to the selected hydraulic hammer. Screenshot of the hydraulic hammer selection part of the developed application is shown in Eq. 1.

Construction duration of selected combination is computed by implementing Eq. 9. Construction cost of hydraulic hammer is computed by Eq. 1 to 8 without fuel cost. Hydraulic hammer is powered by excavator; therefore, fuel cost of the hydraulic hammer is zero. Cost of excavator is also computed by Eq. 1 to 8 but fuel cost is taken as half of the value given by Eq. 7 since the excavator is not fully powered when supplying power for the hydraulic hammer.

Construction duration of selected combination is computed by implementing Eq. 9. Construction cost of hydraulic hammer is computed by Eq. 1 to 8 without fuel cost. Hydraulic hammer is powered by excavator; therefore, fuel cost of the hydraulic
Table 4. Specifications of the construction machines

\begin{tabular}{llll}
\hline $\begin{array}{l}\text { Dozer } \\
\text { Type }\end{array}$ & Price & $\begin{array}{l}\text { Engine } \\
\text { Power }(\mathrm{HP})\end{array}$ & $\begin{array}{l}\text { Size of the } \\
\text { Blade }\left(\mathrm{m}^{3}\right)\end{array}$ \\
\hline D7 & $\$ 750,000$ & 238 & 5.55 \\
D8 & $\$ 1,000,000$ & 312 & 11.8 \\
D9 & $\$ 1,200,000$ & 436 & 16.4 \\
D10 & $\$ 1,500,000$ & 600 & 22 \\
D11 & $\$ 2,200,000$ & 850 & 34 \\
\hline
\end{tabular}

hammer is zero. Cost of excavator is also computed by Eq. 1 to 8 but fuel cost is taken as half of the value given by Eq. 7 since the excavator is not fully powered when supplying power for the hydraulic hammer.

Data about dozers and ripper rate given in Table 1, 2, and 4 are entered into spreadsheet application as shown in Fig. 2. Compressive strength and Schmidt Hammer readings are entered to related cells in line 29 and ripper output estimations for the seven seismic velocity-mechanical property relationships are obtained. Seismic velocitymechanical property relationships are defined at lines 3 to 39 and the obtained ripper output is given at Cells L24 to L30.

Computation of unit cost of selected dozer is given in Fig. 3. Eqs. 1 to 7 are written without any modification and hourly cost of selected dozer is computed. 


\begin{tabular}{|c|c|c|c|c|c|c|c|c|c|c|c|c|}
\hline & Dozer Type & Price & Blade Cap. & Power & IDEAL_TOP & IDEAL_LOW & ADVERSE_TOP & ADVERSE_LOW & & Site Conditions & AVERAGE & \\
\hline & D7 & $\$ 750.000$ & 5,55 & 238 & 1500 & 100 & 750 & 0 & & Selected Dozer & $\mathrm{DgR}$ & i. \\
\hline & D8 & $\$ 1.000 .000$ & 11,8 & 312 & 1800 & 200 & 900 & 0 & & Probability of Suitabili & $95 \%$ & \\
\hline & D9R & $\$ 1.200 .000$ & 16,4 & 550 & 1900 & 220 & 1000 & 0 & & Depreciation & 420,00 & TL/hour \\
\hline & D10R & $\$ 1.500 .000$ & 22 & 600 & 2300 & 400 & 1250 & 0 & & Spare Parts & 222,60 & TL/hour \\
\hline & D11R & $\$ 2.200 .000$ & 34 & 850 & 2800 & 500 & 1500 & 200 & & Operat. \&Maint & 54,60 & TL/hour \\
\hline & & & & & \multicolumn{2}{|c|}{ IDEAL } & \multicolumn{2}{|c|}{ ADVERSE } & & Investment Cost & 151,20 & TL/hour \\
\hline & & & & & $a$ & b & a & b & & Ins. Trans. & 67,20 & TL/hour \\
\hline & & & & D7 & $-141937,5$ & 145022,0 & $-76091,5$ & 77690,4 & & & & \\
\hline & & & & D8 & $-162128,6$ & 165739,4 & $-91309,8$ & 93228,4 & & Fixed Costs & 915,60 & TL/hour \\
\hline & A & $6.720 .000 \varepsilon$ & & D9R & $-170225,0$ & 174026,4 & $-101455,4$ & 103587,2 & & & & \\
\hline & Power & 550 & HP & D10R & $-192365,2$ & 196815,6 & $-126819,2$ & 129483,9 & & & & \\
\hline & $i$ & $8 \%$ & & D11R & $-232847,3$ & 238250,5 & $-131692,0$ & 134663,3 & & Fuel & 310,37 & TL/hour \\
\hline & $\mathrm{N}$ & 8 & year & & & & & & & Oil & 62,07 & TL/hour \\
\hline & $n$ & 2000 & hour/year & & & & & & & Foreman & 9,60 & TL/hour \\
\hline & Diesel Cons. & 0,0855 & It/hp/hour & & & & & & & Operator & 21,60 & TL/hour \\
\hline & Oil Cons. & 0,0171 & It/hp/hour & & & & & & & Oiler & 3,33 & TL/hour \\
\hline & & & & & & & & & & Operating Costs & 406,97 & TL/hour \\
\hline & Exchange R. & 6,3 & TLE & & & & & & & & & \\
\hline & Exchange $\mathrm{R}$. & 5,6 & TL/S & & & & & & & TOTAL UNIT M COST & 1322,57 & TL/hour \\
\hline & Fuel Price & 6,6 & TLliter & & & & & & & & & \\
\hline & Foreman & 20 & TL/hour & & & & & & & Hourly Ripper Output & & \\
\hline & Operator & 15 & TL/hour & & & & & & & Sharma & 412,0 & $\mathrm{~m}^{3} /$ hour \\
\hline & Oiler & 10 & TL/hour & & & & & & & Zukui & 1450,0 & $\mathrm{~m}^{3} /$ hour \\
\hline & & & & & & & & Rook \% & $30 \%$ & Babacan & 1180,5 & $\mathrm{~m}^{\mathrm{s}} /$ hour \\
\hline & & & & & & & & Soil \% & $70 \%$ & Göktan & 1232,3 & $\mathrm{~m}^{3} /$ hour \\
\hline & & & & Cs Rock & Cs Soil & SH (Rock) & SH (Soil) & & & Christaras & 1450,0 & $\mathrm{~m}^{3} /$ hour \\
\hline & & & & 20 & 2 & 30 & 3 & & & Altındağ & 1450,0 & $\mathrm{~m}^{3} /$ hour \\
\hline & $V_{p}$ & Constant & & UCS & & Vel. Rock & Vel Soil & & Vave & Yağız & 1450,0 & $\mathrm{~m}^{3} /$ hour \\
\hline Shat & 0,0842 & $-117,99$ & & 20 & 2 & 7051,78 & 6131,90 & & 6,40786 & & & \\
\hline Zuku & 0,0188 & 0,0848 & & 20 & 2 & 3478.95 & 337,72 & & 3 & Average & 1232,1 & $\mathrm{~m}^{3} /$ hour \\
\hline Bab: & 0,012 & $-5,955$ & & 20 & 2 & 7096,18 & 2174,92 & & 3,6513 & & & \\
\hline Gökt & 0,038 & $-31,18$ & & 20 & 2 & 4684,28 & 3023,84 & & 3,51597 & & & \\
\hline & & & & & & & & & 3 & & & \\
\hline & Power & Constant & & & & & & & 3 & & & \\
\hline Chris & 1,21 & 9,950 & & 20 & 2 & 5842,103739 & 871,2102644 & & 3 & & & \\
\hline Altın & 1,194 & 12,746 & & 20 & 2 & 4784,680223 & 695,5528977 & & & & & \\
\hline Yağı & 3,543 & 2,304 & & 20 & 2 & 6037.91455 & 3152,392452 & & & & & \\
\hline
\end{tabular}

Fig. 2. Spreadsheet application to compute hourly ripper rate

\begin{tabular}{|c|c|c|c|c|c|c|}
\hline & Dist & Empty V & Loaded V & Time (min) & & \\
\hline Haul Route P1 & 750 & 45 & 35 & $=\mathrm{H} 43 / 1000 / 143^{*} 60+\mathrm{H} 43$ & $3 / 1000 / J 43$ & 80 \\
\hline Haul Route P2 & 1250 & 55 & 35 & $\overline{3,5}$ & & \\
\hline \multirow[t]{12}{*}{ Haul Route P3 } & 1000 & 50 & 30 & 3,2 & & \\
\hline & & & & & & \\
\hline & & Load & & 2,5 & & \\
\hline & & Dump & & 1 & & \\
\hline & & Spot & & 2 & & \\
\hline & & & & 14,5 & $\min$ & \\
\hline & & & & & & \\
\hline & & Truok Capacity & & 16 & $\mathrm{~m}^{3}$ & Loose \\
\hline & & & & 12,8 & $\mathrm{~m}^{3}$ & Bank \\
\hline & & \multicolumn{2}{|c|}{ Fuel + Oil Cost + Ope } & 127,0 & TL/hour & \\
\hline & & Fixed Cost & & 113,1 & TL/hour & \\
\hline & & \multicolumn{2}{|l|}{ Unit Hauling Cost } & 5,44 & $\mathrm{TL} / \mathrm{m}^{3}$ & \\
\hline
\end{tabular}

Fig. 3. Spreadsheet application to compute hauling cost

Excavated material is hauled to outside of the construction site by trucks. Cost of hauling depends on the capacity of trucks and hauling distance. Hauling route can be defined as three sections where average velocity of the trucks changes (Fig. 4). The user defines the average empty and loaded velocities and the length of the section. If the haul route consists of less than three sections, distances are given as 0 meters for the unnecessary data cells. Duration of transportation of the truck is computed by the given data. Maneuver time, dump time and loading time are defined and tour time of the truck is computed. Hourly cost of truck is computed by the Eq. 1 to 7 and unit hauling cost is computed by dividing the hourly output by the hourly cost. Total hourly cost is computed by multiplying the unit cost by the hauled volume.

Fixed cost and operating costs of trucks are computed by the following expressions respectively.

$$
\begin{aligned}
& F X_{\text {cost } t_{-} t}=F C C * P C T * C R_{-} E_{-} T L \\
& O P_{{\text {cost } t_{-} t}}=H P_{T} * 0.0855 * U F P * 0.65+\text { Operator }
\end{aligned}
$$




\section{Section 3 \\ Dump Site

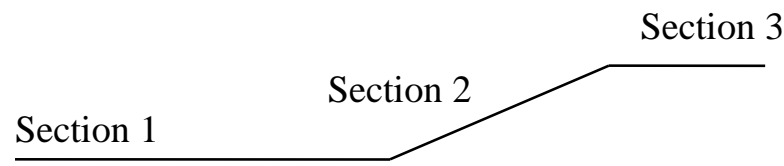 \\ Excavation \\ Site}

Fig. 4. Possible Hauling route geometry

In Eq. 14 FXcost_t represents the fixed cost of truck, FCC is the fixed cost constant used by the Ministry of Environment and Urbanization for the computation of fixed cost of the construction machines, PCT is the purchase cost of the truck in Euro, CR_E_TL is the currency exchange rate between Euro and Turkish Lira. In Eq. 15 OPcost_t represents the operating cost of the truck, HP_t is the power of the engine of the truck in terms of horse power, 0.0855 is the constant used for the hourly fuel consumption of diesel engines, UFP is the unit fuel price of diesel fuel, 0.65 is the correction factor for the estimated fuel consumption of trucks, Operator is the hourly wage of the truck operator.

Duration of ripping the rock which fills the blade of the dozer is computed by the expression given in Eq 16.

$$
\begin{aligned}
& \text { DFB } \\
& =\frac{\text { VLOOKUP(Data! L3; Data! } \$ B \$ 3: \$ 1 \$ 7 ; 3 ; \text { FALSE })}{\text { Data } ! L 24} \\
& * 3600
\end{aligned}
$$

In Eq. 16 DFB represents the duration of filling the dozer blade in seconds, and the VLOOKUP comment of MS Excel provides the corresponding blade capacity of the dozer by considering the utilized dozer which is defined at cell L3. The hourly ripping capacity of the dozer is estimated at cell L24 and the dozer capacity to hourly output gives the duration of the filling the dozer blade.

Tour time and hourly output is computed by the expressions given in Eqs. 17 and 18.

$$
\mathrm{TT}=(\$ C \$ 11+\$ C \$ 12+\mathrm{C} 13+\$ C \$ 14) / 60
$$

In Eq. 17, TT represents tour time. Eq. 17 is the implementation of Eq. 9. In Eq. 17 data cells C11 to $\mathrm{C} 14$ represent return, hauling, ripping, and spot times which are illustrated in Figure 5. Eq. 18 estimates the hourly output of the dozer.
$\mathrm{HO}=\$ \mathrm{C} \$ 15 * 60 / \mathrm{C} 16$

In Eq. 18, HO represents hourly output of the dozer which breaks the rock by ripping. Eqs. 16 to 18 are implemented for the seven seismic velocity estimations and seven different ripper output are obtained. Construction duration and cost are obtained by Eqs. 19 and 20 respectively.

$\mathrm{CD}=\$ \mathrm{C} \$ 6 / \mathrm{C} 17 / \mathrm{D}$ ata $\$ \mathrm{C} \$ 48$

CC $=$ C18 $*$ Data! \$L \$21 * Data! \$C \$48+

Data! \$K\$56 * RipperCost' ! \$C\$6

In Eq. 19, CD represents the construction duration in work hours. Cell C6 illustrates the total volume of excavation, $\mathrm{C} 17$ represents the hourly ripping rate and Cell $\mathrm{C} 48$ represents the daily working hours. In Eq. 20 Cell C18 represents duration of construction which is CD, Cell L21 represents the total unit cost of the construction machine computed by the summation of Eqs. 14 and 15. Cell K56 represents the unit cost of hauling. Implementation of Eqs. 19 and 20 are illustrated in Fig. 5.

Rock excavation by ripping increases the amount of rock excavation thus volume of hauling. Amount of excavation is computed for both hydraulic hammer and ripping as given in Figure 8. Total excavation cost and duration is also computed by Eq. 9 finally overhead costs and rental costs are added and total cost is obtained.

\section{Case Study}

Proposed construction machine selection procedure is tested on the public housing construction at the campus site of the Inonu University, Malatya, Turkey. The construction consists of 72 single houses with $120 \mathrm{~m}^{2}$ settlement area. The horizontal spacing between the houses is 12 meters. The layout of the public housing project is given in Fig. 6 . 


\begin{tabular}{|c|c|c|c|c|c|c|c|c|c|c|}
\hline & A & $\mathrm{B}$ & C & D & $E$ & $\mathrm{~F}$ & G & $\mathrm{H}$ & 1 & $\mathrm{~J}$ \\
\hline \multicolumn{11}{|l|}{1} \\
\hline 2 & & Quantity & & & & & & & & \\
\hline 3 & & Width & 10 & meter & Spacing & & 13 & $\mathrm{~m}^{2}$ & & \\
\hline 4 & & Length & 12 & meter & No of House & & 72 & & & \\
\hline 5 & & Area & 120 & $\mathrm{~m}^{2}$ & \multicolumn{2}{|l|}{ Average Dept } & 2 & $\mathrm{~m}$ & & \\
\hline 6 & & Volume (Ripper) & 36000 & $\mathrm{~m}^{3}$ & & & & & & \\
\hline 7 & & Volume (Hydraulic Hammer) & 17280 & $\mathrm{~m}^{3}$ & & & & & & \\
\hline 8 & & Empty Velocity & 2,5 & $\mathrm{~m} / \mathrm{s}$ & \multicolumn{2}{|c|}{ Average Ripping Distance } & 55 & $\mathrm{~m}$ & & \\
\hline 9 & & Loaded Velocity & 1,5 & $\mathrm{~m} / \mathrm{s}$ & \multicolumn{2}{|c|}{ Average Grading Distance } & 75 & $\mathrm{~m}$ & & \\
\hline 10 & & Ripping velocity & 1 & $\mathrm{~m} / \mathrm{s}$ & & & & & & \\
\hline 11 & & Empty Return & 30 & $\mathrm{sn}$ & & & & & & \\
\hline 12 & & Loaded Haul & 50 & sn & & & & & & \\
\hline 13 & & Ripping & 98,6 & 31,1 & 37,8 & 36,3 & 31,1 & 31,1 & 31,1 & \\
\hline 14 & & Spot Time & 10 & sn & & & & & & \\
\hline 15 & & Ripped Quantity & 16,4 & & & & & & & \\
\hline 16 & & Tour time & 3,1 & 2,0 & 2,1 & 2,1 & 2,0 & 2,0 & 2,0 & $\min$ \\
\hline 17 & & Output & 313,0 & 487,6 & 462,0 & 467,5 & 487,6 & 487,6 & 487,6 & $\mathrm{~m}^{3} /$ hour \\
\hline 18 & & Duration & 12,8 & 8,2 & 8,7 & 8,6 & 8,2 & 8,2 & 8,2 & days \\
\hline 19 & & Direct Cost & 396351,5 & 254415,8 & 268537,2 & 265369,7 & 254415,8 & 254415,8 & 254415,8 & $\mathrm{TL}$ \\
\hline 20 & & Delay & 7,0 & 5,0 & 5,0 & 5,0 & 5,0 & 5,0 & 5,0 & \\
\hline 21 & & Indirect Cost & 7700,0 & 5500,0 & 5500,0 & 5500,0 & 5500,0 & 5500,0 & 5500,0 & $\mathrm{TL}$ \\
\hline 22 & & & & & & & & & & \\
\hline 23 & & Total Cost & 404051,5 & 259915,8 & 274037,2 & 270869,7 & 259915,8 & 259915,8 & 259915,8 & \\
\hline 24 & & & & & & & & & & \\
\hline 25 & & Mean & 284088,79 & 53235,60 & & & & & & \\
\hline 26 & & & & & & & & & & \\
\hline 27 & & Probability of being cheaper than implemented $\mathrm{m}$ & $92 \%$ & & & & & & & \\
\hline 28 & & Probability of being cheaper than selected hh & $100 \%$ & & & & & & & \\
\hline
\end{tabular}

Fig. 5. Spreadsheet application to compute ripper cost

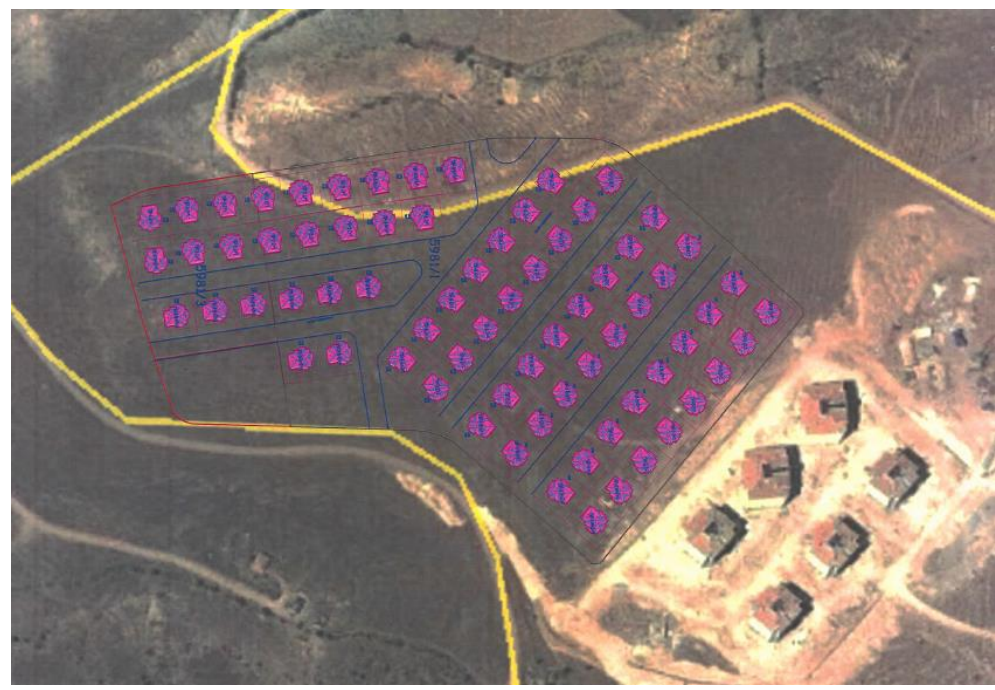

Fig. 6. Lay-out of the public housing project and the excavation plans

Public houses were constructed at a hillside with cascaded rows. Depth of foundation is 1 meter at the front face and 3 meters at the back side of the garden. As a result average depth of excavation is taken as 2 meters. Landscape project does not require excavation of the spacing between the houses. Soil formation of the construction site is conglomerate. Conglomerate has the largest coarsegrained structure in the crumbled sedimentary rocks, which is formed as a result of gaining strength under the pressure of sand and gravel.
Grain size distributions range from 2-40 $\mathrm{mm}$ and the existing grains have round shapes. The conglomerate is connected with fine-grained cement and is a highly porous rock. There is a strong relationship between the physicomechanical properties and porosity of the rocks. Due to its high porosity, the mechanical strength and the wave velocity of conglomerate are low [26]. Specimens obtained during site investigation are illustrated in Fig. 7. 


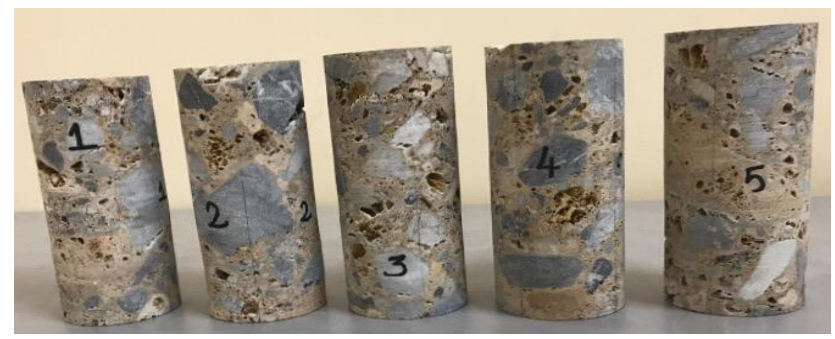

Fig. 7. Illustration of the site specimens

Site investigations reveal that approximately $70 \%$ percent of the soil is common earth and 30\% of the soil is conglomerate. Schmidt hammer readings as well as uniaxial compression test are performed on the conglomerate samples. The tests are conducted at Material Laboratory of Mining Engineering Department of İnönü University. Results of the site investigation are given in Table 5.

Average of Schmidt hammer and compressive strength test results are substituted into the seismic velocity expressions given in Table 2. Ripper rate is obtained by Eq. 8. Implementation of ripper output procedure as spreadsheet application is shown in Fig. 1.

Excavation of the foundations can also be executed by ripping. In this case foundations cannot be excavated foundation plan; excavation would have to cover the spacing between the houses. Adjusted excavation plan of the ripping by dozer is shown in Fig. 8.

Site investigations revealed that construction site and weather conditions are suitable for excavation as the weather and soil is dry and no tree roots, heavy rock or obstacle exists at the excavation area. Ripping along the hill provides the optimum ripper rate. Therefore, average production rate is used for the estimation of ripping rates. On the other hand, production rates are valid when the dozer rips without stopping. The earthwork process includes not only ripping, but also crushing and moving the ripped material.

Fig. 8 illustrates the region to be ripped and the haul distance of ripped material by dozer. Dozer retraces the ripped region to grind the excavated material. This makes approximately 55 meters distance to go without a notable drawbar load on the dozer. Then dozer moves the ripped earth by using its blade approximately 15 meters away from the excavation site. As a result, the dozer goes 55 meters with no load and 70 meters with grading the ripped material. Average empty and loaded velocities are assigned as $8.0 \mathrm{~km} / \mathrm{h}$ and $5.4 \mathrm{~km} / \mathrm{h}$ respectively. Spot time is taken as 10 seconds for shifting the gear. Aforementioned data is entered into appropriate cells represented in Figure 5 and hourly output is computed. Volume of transported material for each cycle depends on the size of the dozer blade given in Table 4 .

A loader loads the excavated material to hauling trucks outside of the excavation strip and then the earth is moved to dump area. The cost of hauling will be the twice of the hauling cost of excavation by hydraulic hammer. Security, illumination, heating and ventilation, insurance, meals, cleaning, and salaries of technical staff are classified as overhead costs. In the beginning of the construction the construction site is relatively small thus the overhead cost would not be high and can be assumed as 500 TL/day. Similarly, early finish of public houses can be beneficial for the occupants for $2400 \mathrm{TL} / \mathrm{day}$. One third of the benefit can be given to the contractor as early finish reward which makes 600TL/day. Consequently, the contractor would gain or save 1100 TL for each day of early finish.

Duration of excavation directly effects the duration of construction as water insulation and construction of foundations can start when the excavation finishes. However, whole excavation is not necessarily be finished to start water insulation and construction of foundations. It is assumed that water insulation and foundation tasks can start if half of the excavation is completed. 
Table 5. Mechanical properties of the specimens

\begin{tabular}{lccccccc}
\hline $\begin{array}{l}\text { Specimen } \\
\text { No }\end{array}$ & $\begin{array}{c}\text { Natural Unit } \\
\text { Weight } \\
\left(\mathrm{kN} / \mathrm{m}^{3}\right)\end{array}$ & $\begin{array}{c}\text { Dry unit } \\
\text { Weight } \\
\left(\mathrm{kN} / \mathrm{m}^{3}\right)\end{array}$ & $\begin{array}{c}\text { Saturated } \\
\text { Unit Weight } \\
\left(\mathrm{kN} / \mathrm{m}^{3}\right)\end{array}$ & $\begin{array}{c}\text { Volumetric } \\
\text { Water } \\
\text { Content }(\%)\end{array}$ & Porosity (\%) & $\begin{array}{c}\text { Schmidt } \\
\text { Hammer } \\
\text { Hardness }\end{array}$ & $\begin{array}{c}\text { Compressive } \\
\text { Strength } \\
(\mathrm{MPa})\end{array}$ \\
\hline 1 & 23.711 & 23.495 & 23.936 & 1.846 & 4.422 & 18.50 & 20.50 \\
2 & 23.642 & 23.436 & 23.887 & 1.934 & 4.621 & 18.10 & 19.55 \\
3 & 23.701 & 23.466 & 23.936 & 1.980 & 4.737 & 18.20 & 19.62 \\
4 & 23.927 & 23.721 & 24.152 & 1.805 & 4.366 & 19.30 & 23.60 \\
5 & 23.515 & 23.299 & 23.750 & 1.923 & 4.567 & 18.80 & 20.82 \\
Average & 23.701 & 23.485 & 23.927 & 1.898 & 4.542 & 18.58 & 20.82 \\
\hline
\end{tabular}

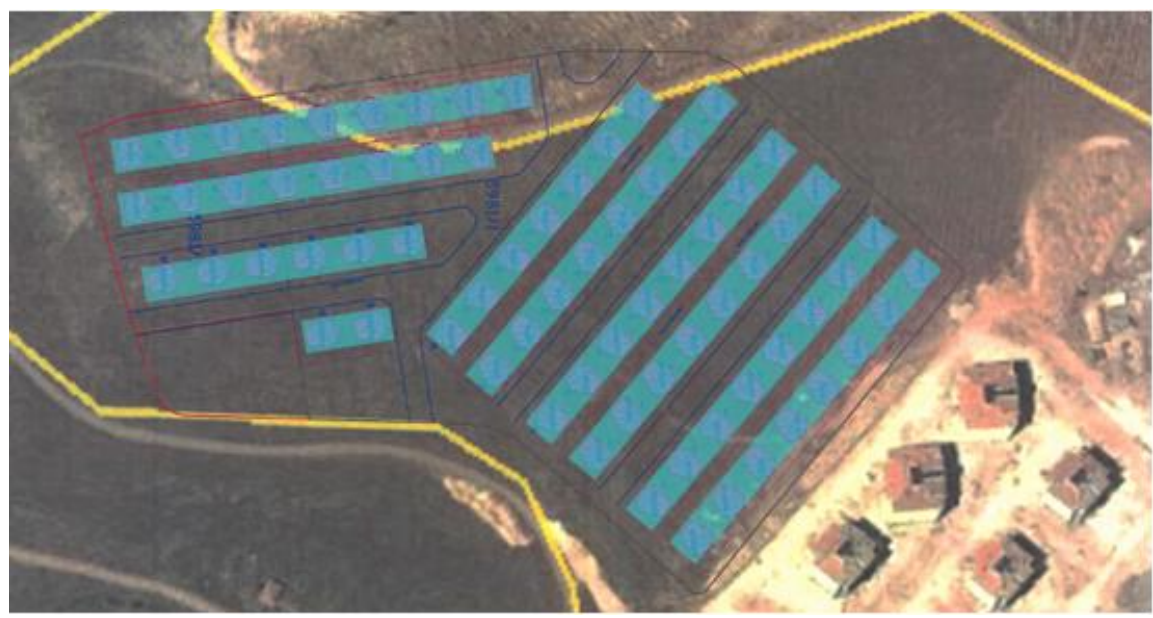

Figure 8. Excavation plan if the site is ripped

Table 6 presents the predicted total costs of excavation and the uncertainty of the excavation according to the corresponding dozer. Obtained values are compared with the exact cost of excavation and $\mathrm{z}$-values for each prediction is computed. The z-values are computed by subtracting the predicted excavation cost from the exact cost and dividing the result by the uncertainty. The probabilities of cost of excavation by ripping being lower than the cost of excavation by back hoe excavator are computed by using z-value table.

Probability computation is also repeated for the excavation with hydraulic hammer. Therefore, many excavation alternatives can be evaluated and compared. Analysis results reveal that larger construction equipment has cheaper unit rock breaking cost. In addition to this, larger construction machine finishes the job earlier and
Table 6. Probabilities of cost of rippers being cheaper than back-hoe excavator

\begin{tabular}{lccc}
\hline $\begin{array}{l}\text { Dozer } \\
\text { Type }\end{array}$ & $\begin{array}{c}\text { Total Cost } \\
\text { (TL) }\end{array}$ & $\begin{array}{c}\text { Uncertainty } \\
\text { (TL) }\end{array}$ & $\mathrm{P}($ CostR $<$ CostEx $)$ \\
\hline D7 & 617861.31 & 99598.09 & $0 \%$ \\
D8 & 364940.18 & 79978.53 & $47 \%$ \\
D9 & 316392.37 & 80954.17 & $70 \%$ \\
D10 & 259433.78 & 61891.06 & $95 \%$ \\
D11 & 217563.27 & 51071.95 & $100 \%$ \\
\hline
\end{tabular}

reduces the overhead costs. Therefore, larger construction equipments have higher likelihood of finishing the job cheaper.

\section{Conclusion}

In this study selection of excavator is transformed into time cost trade-off problem. The problem is 
tested on foundation excavation of mass housing project in Malatya, Turkey. Usually economic analysis of construction machines are conducted by taking only direct costs into account and neglecting the overhead costs and opportunity costs. Economic impact of construction duration is omitted, which may lead to wrong decision. The case problem is analyzed by considering site conditions, hauling distance, machine specifications, and indirect costs. Consequently, many omitted details are included in the analysis. The proposed methodology is implemented as spreadsheet application and every contractor can utilize the method and may reduce total cost of construction.

Compressive strength and seismic velocity relationship models obtained from literature review are used to predict seismic velocity value from unconfined compressive strength of in situ samples. This approach avoids the necessity of conducting in situ seismic velocity measurements to predict ripper rates. Execution and interpretation of seismic velocity measurement is difficult and costly for small and medium sized contractor. The proposed seismic velocity prediction approach may reduce the cost, duration, and complexity of required in situ tests. Computation of ripper rate by unconfined compressive strength data is another benefit for the contractors.

The study makes comparison between ripping and hydraulic hammer possible. Many varieties of hydraulic hammers and suitable excavators are defined to spreadsheet application. Unit cost and construction duration can be computed for many hydraulic hammer alternatives. Contractor can test and evaluate the cost and duration of earthwork in a short time and can properly select the most suitable construction machine. The proposed model and developed application makes examination of different alternatives possible and reduces the workload of project planners. Consequently, the proposed method can reduce the cost of earthwork tasks and provides competitive advantage for the contactors.

The analysis results revealed that the selection of construction machine has important effect on the cost and duration of construction. The developed system does not take into account effects of weather. Probabilistic weather conditions and site management can be added to uncertainty analysis of the cost and duration. Some of the capabilities of Geographic Information System can be included and conditions of hauling roads might be investigated in more detail. In addition to this, variability of the soil conditions can be predicted by Krigging interpolation. Digital Elevation Model of the hauling zone can be loaded and the tour time of the construction machines can be predicted by considering the instantaneous slope resistance and more realistic results can be obtained. The developed system assumes that the uncertainties are normally distributed. Other probability distribution might be considered to compare the effects as further study.

\section{Declaration of conflicting interests}

The author(s) declared no potential conflicts of interest with respect to the research, authorship, and/or publication of this article.

\section{References}

[1] Kartam N, Flood I (2000) Construction simulation using paralel computing environments. Automation in Construction, 10:69-78.

[2] Shi J, Abourizk S (1998) Continuous and combined evenprocess models for simulating pipeline construction. Construction Management and Economics, 16:489-498.

[3] Tserng HP, Ran B. Russell J S (2000) Interactive path planning for multi-equipment landfill operations. Automation in Construction, 10:155168.

[4] Shi JJ, Zeng SX, Tam CM. Modelling and simulation of public housing construction in Hong Hong. 1998 Winter Simulation Conference, 13-16 Dec. 1998, Washington, DC, USA.

[5] Sağlam B, Bettemir ÖH (2018) Estimation of duration of earthwork with backhoe excavator by Monte Carlo Simulation. Journal of Construction Engineering, Management and Innovation, 1(2): 85-94.

[6] Bettemir ÖH (2018) Development of spreadsheet based quantity take-off and cost estimation application. Journal of Construction Engineering, Management and Innovation, 1(3):108-117. 
[7] Munshaw V, Trivedi J (2016) Selection of tower cranes through Artificial Neural Network model. Journal of Image Processing \& Pattern Recognition Progress, 3(2):67-79.

[8] Trivedi JS, Kumar R (2013) Optimization of construction equipment utility using Neural Networks. NICMAR: Journal of Construction Management, 28(3):43-50.

[9] Rausch P (2010) Intelligent performance and cost analysis of construction machines' data. Journal of Intelligent Computing, 1(1):13-19.

[10] Lim HC, Lee HC, Lee DE. Economic excavator configuration for earthwork scheduling. International Conference on Architecture and Civil Engineering, January 2018, London, UK.

[11] Karshenas S, Farid F (1987) Multiloader-truck fleet selection for earth moving. Transportation Research Record, 1186:51-65.

[12] Karshenas S (1989) Truck capacity selection for earthmoving. Journal of Construction Engineering and Management, 115(2):212-227.

[13] Chan CMR, Harris FC (1989) A database/spreadsheet application for equipment selection. Construction Management and Economics, 7(3):235-247.

[14] Unit Price Book, Republic of Turkey Ministry of Environment and Urbanization, Directorate of Higher Technical Board, Construction and Installation Unit Prices.

[15] Caterpillar Inc. (1997). Caterpillar performance handbook. Caterpillar.

[16] Nunnally SW. Construction Methods and Management. 6th edition, McGraw-Hill, USA, 2003.

[17] Peurifoy RL, Schexnayder CJ. Construction Planning, Equipment and Method, 6th edition, McGraw-Hill, USA, 2002.

[18] Sharma PK, Singh TN (2008) A correlation between $\mathrm{P}$-wave velocity, impact strength index, slake durability index and uniaxial compressive strength. Bulletin of Engineering Geology and the Environment, 67(1):17-22.
[19] Zukui L, Xinxu Z, Jinhai Z, Daixu T, Yongsong T, Jing Y, Yanqing L (2001) The experiment investigation of the correlation of acoustic logging and rock mechanical and engineering characteristics. In: Wang $\mathrm{S}, \mathrm{Fu} \mathrm{B}, \mathrm{Li}$ Z. (ed) Frontiers of Rock Mechanics and Sustainable Development in the 21st Century, CRC Press, 2001, pp. 89-92.

[20] Babacan AE, Ersoy H, Gelişli K (2012) Kayaçların fiziksel, mekanik ve elastik özelliklerinin ultrasonik hız tekniği ve zaman-frekans analiziyle belirlenmesi: bej kireçtaşları (KD Türkiye) üzerine örnek bir çalışma. Jeoloji Mühendisliği Dergisi, 36(1):63-73.

[21] Goktan RM. Theoretical and practical analysis of rock rippability. Ph.D. Thesis, Istanbul Technical University, 1988.

[22] Christaras B, Mariolakos I, Foundoulis J, Athanasias S, Dimitriou A. Geotechnical input for the protection of some Macedonian Tombs in Northern Greece. 4th International Symposium Conservation of Monuments in The Mediterranean Basin, 6-11 May 1997, Rhodes, Greece, pp. 125132.

[23] Altindag R (2012) Correlation between P-wave velocity and some mechanical properties for sedimentary rocks. Journal of the Southern African Institute of Mining and Metallurgy, 112(3):229237

[24] Yagiz S (2011) P-wave velocity test for assessment of geotechnical properties of some rock materials. Bulletin of Materials Science, 34(4):947.

[25] Mendenhall WM, Sincich TL. Statistics for Engineering and the Sciences. Chapman and Hall/CRC, 2016.

[26] Morris J. Geology Book, The. New Leaf Publishing Group, 2000. 